\title{
PRE-SERVICE COMPUTER TEACHERS' TENDENCIES TOWARDS THE USE OF MOBILE TECHNOLOGIES: A TECHNOLOGY ACCEPTANCE MODEL PERSPECTIVE
}

\author{
ÜnalÇakıroğlu [cakiroglu@ktu.edu.tr], Karadeniz.Technical Universtiy,Seyfullab Gökoğlu \\ [sgokoglu@kastamonu.edu.tr], Kastamonu University, Mücabit Öztürk.[mucahitozturk@aksaray.edu.tr], \\ Aksaray University, Turkey
}

\begin{abstract}
Drawing on the Technology Acceptance Model (TAM), this exploratory study examines the preservice teachers' adoption of mobile technologies through the factors of current use, instructional use and future use in their teaching practices. Participants were 466 pre-service computer teachers enrolled at a public university in Turkey. A questionnaire developed by the researchers was used to collect data. Results indicated that the current use and instructional use factors had a strong positive correlation and also there was a similar correlation with the factor of future use and current use. Relationships between current, instructional, and future use of mobile technologies explained within the context of perceived usefulness, ease of use, and behavioural intention constructs of the TAM.
\end{abstract}

\section{Abstract in Turkish}

Teknoloji Kabul Modelini (TKM) temele alınarak gerçekleştirilen bu keşfedici araştırmada, öğretmen adaylarının mobil teknolojileri benimseme durumları mevcut kullanım, öğretimsel kullanım ve gelecekteki öğretim uygulamalarındaki kullanım durumları çerçevesinde incelenmiştir. Araştırmanın katılımcılarını Türkiye'deki bir üniversitede öğrenim gören 466 bilişim teknolojileri öğretmen adayı oluşturmaktadır. Veri toplama aracı olarak araştırmacılar tarafından geliştirilen bir anket kullanılmıștır. Araştırma bulguları mevcut kullanım ve öğretimsel kullanım faktörleri arasında yüksek düzeyde olumlu bir ilişki olduğunu; benzer şekilde mevcut kullanım ile gelecekteki kullanım faktörleri arasında da benzer bir ilişki düzeyi olduğunu göstermektedir. Mobil teknolojilerin mevcut, öğretimsel ve gelecekteki kullanım durumları arasındaki ilişki TKM'nin algılanan fayda, kullanım kolaylığı ve davranışsal niyet gibi temel bileşenleri çerçevesinde açıklanmıştır.

Keywords: mobile technologies, pre-service computer teachers, technology acceptance model, future tendencies

\section{Introduction}

In recent years, in an increasingly digital education the integration of mobile technologies in the classrooms continues to grow and is playing significant role in the technology integration applications (Sánchez-Prieto, Olmos-Migueláñez, \& García-Peñalvo, 2014; Fulantelli, Taibi, \& Arrigo, 2015). In this sense scholars point out that teachers should be experienced in using technology and also should know how to integrate technology in to the classrooms as well (Dexter, Doering, \& Riedel, 2006; Goktas, Yildirim, \& Yildirim, 2009). To this end, many efforts were provided to train in-service and pre-service teachers. Since pre-service teachers are considered more close to the novel technologies and in-service teachers have formed some habits about technology use, some researchers suggest to give more attention to pre-service technology 
integration trainings (Cacho, 2017; Baydas \& Göktaş, 2016). As mobile learning becomes important, it is critical that pre-service teachers develop skills to use mobile technologies in their classrooms.

In this sense, the number of studies about both in-service and pre-service teachers' use of mobile technologies continues to grow (Joo, Lee, \& Ham, 2014; Kim, Chun, \& Lee, 2014; Kuo, Liu, \& Ma, 2013; Yamakawa et al., 2013; Jaradat, 2013). Also, Kafyulilo, (2014) pointed out that teachers should play significant roles in the design process of mobile learning environments.

For instance, Kusskonmaz (2011) noticed that the majority of the teachers found their mobile learning practices valuable for teaching profession. Uzunboylu and Ozdamli (2011) with a survey study found that teachers' perceptions towards mobile learning were generally positive. In another study, Hur et al. (2015) explained factors such as usefulness, ease of use and self-efficacy affecting pre-service teachers' intention to use mobile devices and found that perceived usefulness was the strongest predictor.

Within a general view Nistor (2014) suggested to provide some explorative studies in order to explain the intentions and actual use of new technologies. However, only a few studies focused on pre-service teachers' intention to use mobile devices in their future practices (Acarli \& Sağlam, 2015; Valtonen et al., 2015; Teo, 2012; Camilleri \& Montebello, 2011). Thus, it is still a question that, whether pre-service teachers know how to use mobile technologies can they easily integrate in the classroom or will they really tend to use them in their future practices (Lei, 2009; Sadaf, Newby, \& Ertmer, 2012; Valtonen, 2011).

In Turkey, in recent years, a new reform project (Fatih Project) about the integration of new technologies into classrooms is planned for implementation throughout the country. Considering computer teachers as more experienced in using new technologies, the administration gave a responsibility to computer teachers to inform other teachers in adoption process. In fact, where all of the pre-service teachers delivered a compulsory ICT course in the first year, students generally develop skills about the use of computers such as Office programs; however, they cannot learn the ways of integrating ICT in their classrooms. Therefore, computer teachers' beliefs, perspectives and skills in using new technologies become crucial in the integration process. Also, understanding the relationships among the various factors of acceptance of new technologies may provide hints about the use of new technologies in the future. Since smartphones, tablets, PDAs or other mobile technologies are seen important part of the project, pre-service computer teachers' perspectives about using mobile technologies and their intentions to use them in educational context may provide valuable information about the success of the project. In this circumstance, understanding pre-service computer teachers' intentions of using mobile technologies in their future practices may provide ideas for program developers or instructional designers.

On the other hand, when dealing with the integration of a new technology into classrooms, "acceptance" comes to front as the prominent element of the stakeholders; teachers, students, administers or others. (Wang, Wiesemes, \& Gibbons, 2012; Murray \& Olcese, 2011; Chen, Looi, $\&$ Chen, 2009). In this context, various studies have investigated the intentions by adopting the acceptance models about as a framework. In this regard, we used Technology Acceptance Model (TAM) as a theoretical framework to explore the current and future use of mobile technologies among pre-service teachers. 


\section{Theoretical Framework}

Davis, Bagozzi, and Warshaw (1989) modelled the factors influence on users' decisions when they faced with a new computer technology. He addressed that perceived usefulness and perceived ease of use were two main factors in this acceptance process. Attitudes toward use and behavioural intentions to use are and actual system use are the other factors in the process. Figure 1 briefly describes the acceptance process TAM model.

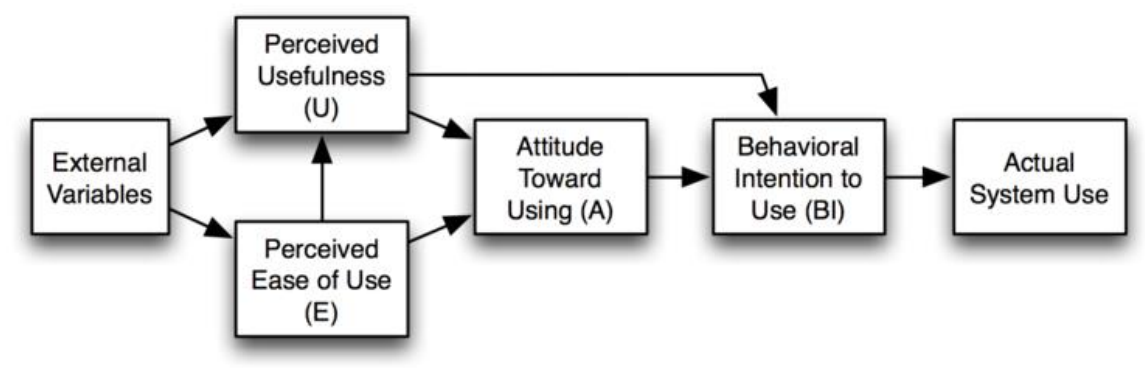

Figure 1. The Technology Acceptance Model

In the model; perceived usefulness is about the beliefs that a particular system would enhance his or her job performance. Perceived ease of use refers the amount of less provided by a particular system.

TAM has been widely used in technology integration studies as a guide for the applications or as a mean for exploring the integration process (Yuen \& Ma, 2008; Holden \& Rada, 2011; Ma, Andersson, \& Streith, 2005; Teo, 2012). Specifically, in the context of mobile learning some studies also used TAM as a framework. For instance, Phuangthong and Malisawan (2005) reported that TAM was helpful to understand factors affecting mobile learning adoption with $3 \mathrm{G}$ technology. Jairak, Praneetpolgrang, and Mekhabunchakij (2009) addressed that the unified theory of acceptance and use of technology based upon TAM was able to explain university students' mobile learning acceptance. Menzi, Önal, and Çalışkan (2012) drawing TAM as a framework, examined the current use of mobile technologies and attitudes towards the use of these technologies for instructional purposes. In addition, Park, Nam, and Cha (2012) confirmed that the university students' behavioural intention to use mobile learning could be explained via the TAM. Darren Pullen et al. (2015) used the adopted version of TAM (unified theory of acceptance and use of technology) model to examine Malaysian pre-services teachers' use of mobile technology in education. The results showed that performance expectancy, effort expectancy, social influence, attitude toward technology and self efficiently were significant determinants of behavioural intentions to use mobile devices for learning. Sánchez-Prieto, Olmos-Migueláñez, and García-Peñalvo (2016) explored the behavioural intention in using mobile devices within the future teaching practice of pre-service primary education teachers through TAM. The results showed that the stronger relationships were those established between perceived usefulness and behavioural intention, perceived ease of use and perceived usefulness.

In this study, in order to gain a better understanding of the pre-service computer teachers' acceptance of mobile technologies we used TAM as a framework. An attempt was made to show the relationships between pre-service computer teachers' current use of mobile technologies, use for instructional purposes and their tendencies in future teaching practices. In line with the purpose of the study, the following research questions were directed: 
1. How do pre-service computer teachers perceive mobile technologies in terms of their current use, instructional use and future teaching practices within the conceptualization of TAM?

2. Do pre-service computer teachers' perceived use of mobile technologies in terms of current, instructional purpose and future teaching practice have statistical correlation among each other?

\section{Methods}

In this study, the pre-service teachers' perspectives were collected with five-point Likert type items (from strongly disagree (0) to strongly agree (4)) questionnaire. TAM was used as a framework to construct an item pool was for the draft questionnaire. Then the items were developed and assigned to the sub-sections through five experts' opinions (two of them have expertise on scale development and the research area of three is about mobile learning). Considering the research problems, the sub-sections of the questionnaire were taken as Current Use, Instructional Use, and Future Use. Many items of the instrument used in this study were derived from previously validated which are shown in Table 1.

Table 1: The references used to develop the questionnaire

\begin{tabular}{|c|c|c|}
\hline Status of Use & Items & References \\
\hline Current Use & 8 & Aktaş (2007); Ma, Andersson, \& Streith (2005); Yong-Wee et al. (2010) \\
\hline Instructional Use & 8 & $\begin{array}{l}\text { Aktaş (2007); Hu, Clark, \& Ma (2003); Koca (2006); Ma et al. (2005); Turan } \\
\text { (2011); Yong-Wee et al. (2010) }\end{array}$ \\
\hline Future Use & 7 & $\begin{array}{l}\text { Aktaş (2007); Koca (2006); Turan (2011); Wang, Wu, \& Wang (2009); } \\
\text { Yong-Wee et al. (2010) }\end{array}$ \\
\hline
\end{tabular}

Since we used the Turkish version of the questionnaire, the overall reliability Cronbach $\alpha$ was .88 which can be considered as acceptable level (Creswell, 2005). The $\alpha$ values for Current Use, Instructional Use, and Future Use were.76, .79, .78 respectively.

The questionnaire was administered to the 466 pre-service teachers $\left(3^{\text {rd }}\right.$ and $4^{\text {th }}$ grades; 243 male $(52.1 \%)$ and 223 female (47.9\%)) enrolled in Computer \& Instructional Technology (CEIT) department. The demographic data is briefly outlined in Table 2.

Table 2: Demographic data of the participants

\begin{tabular}{llll}
\hline & & $\mathrm{f}$ & $\%$ \\
\hline Gender & Male & 243 & 52.1 \\
& Female & 223 & 47.9 \\
Grade & $3^{\text {rd }}$ grade & 311 & 66.7 \\
& $4^{\text {th }}$ grade & 155 & 33.3 \\
\hline
\end{tabular}

\section{Results and Discussion}

The responses to the items under current use, instructional use and current use factors were analysed descriptively and then the correlations among three factors were defined.

The participants' current use of mobile technologies is shown in Figure 1. 


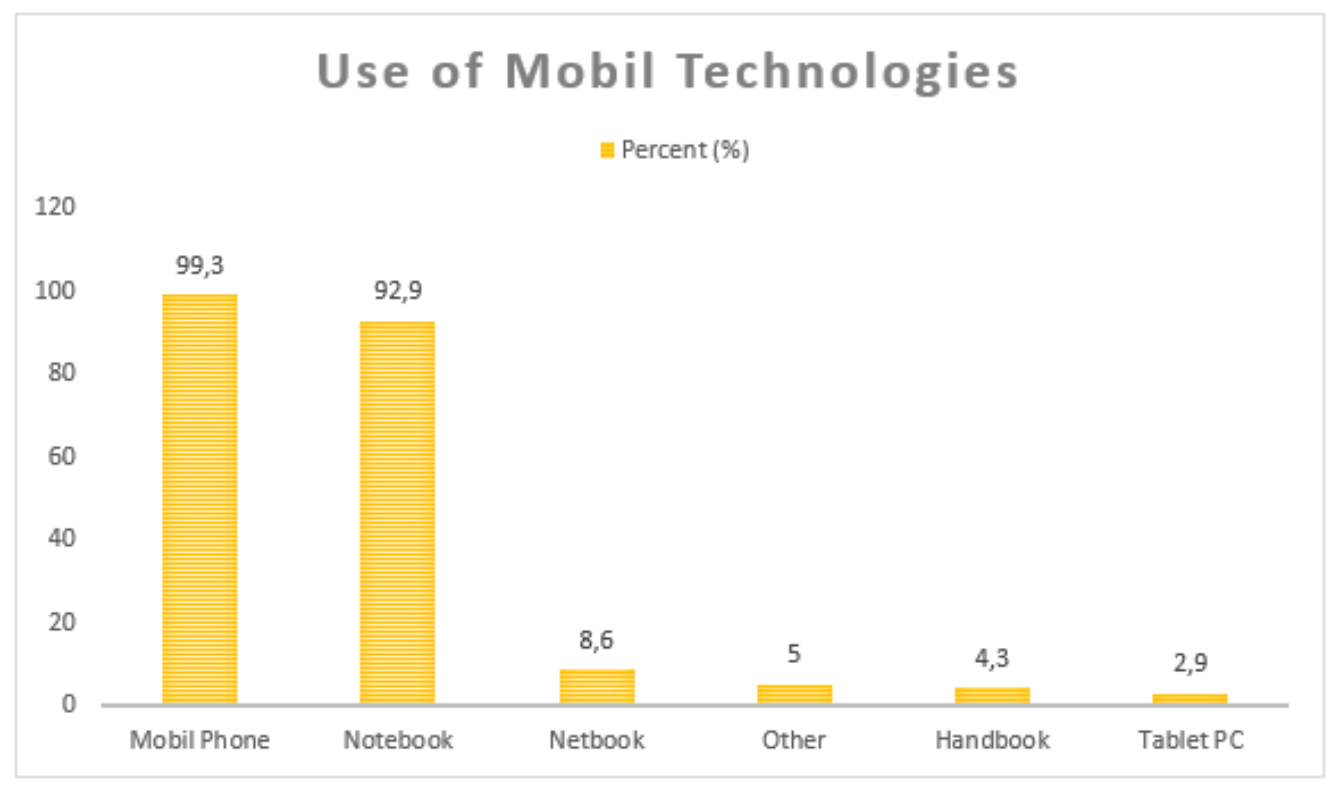

Figure 1. Mobile technology usage of the participants

It is seen that, pre-service computer teachers have mostly use mobile phones $(99.3 \%)$ and notebooks $(92.9 \%)$ as mobile technologies. Tablet PCs $(2.9 \%)$ have the frequency. Notebooks, netbooks, handbooks and others are used as mobile technologies among pre-service teachers.

The responses of pre-service teachers about current use of mobile technologies are shown in Table 3.

Table 3: Current use of mobile technologies

\begin{tabular}{lrr}
\hline Items & M & \multicolumn{1}{l}{ SD } \\
\hline S1 - It is easy learning to use mobile technologies. & 3.59 & .643 \\
S2 - I find the use of mobile technologies understandable. & 3.57 & .760 \\
S3 - I like using mobile technologies. & 3.51 & .707 \\
S4 - It is easy to do whatever I want with mobile applications. & 3.38 & .766 \\
S5 - I can deal efficiently with technical problems of the mobile devices. & 2.82 & .917 \\
S6 - I cannot use mobile devices having complex designs easily. & 2.18 & 1.289 \\
S7 - Mobile technologies support me to do my work more easily. & 3.37 & .747 \\
S8 - Mobile technologies enable me to access information instantly. & 3.46 & .727 \\
Overall & 3.21 & \\
\hline
\end{tabular}

* Arranged as negative in terms of meaning

The responses revealed that pre-service computer teachers generally have positive perspectives towards using mobile technologies $(\mathrm{M}=3.21)$. A considerable amount of them found it easy to learn to use mobile technologies $(M=3.59)$. Also they had positive perceptions that mobile technologies were accurate and understandable $(\mathrm{M}=3.57)$. In their daily life mostly pre-service computer teachers enjoy using mobile technologies $(\mathrm{M}=3.51)$. On the other hand, their perspectives indicate that the design features of mobile devices may cause limitations in using mobile technologies. Pre-service teachers also perceived that mobile technologies can facilitate their work. The pre-service teachers' responses given for the items related to the tendencies towards instructional use of mobile technologies were presented in Table 4. 
Table 4: Instructional use of mobile technologies

\begin{tabular}{lrr}
\hline Items & M & \multicolumn{1}{c}{ SD } \\
\hline S9 - Mobile technologies facilitate teaching. & 3.25 & .85 \\
S10 - Mobile technologies will enable me to use time efficiently during teaching. & 3.00 & .91 \\
S11 - Mobile technologies will enhance students' learning performance. & 2.95 & .95 \\
S12 - Mobile technologies will enhance my productivity in my profession. & 3.12 & .89 \\
S13 - I get stressed by the use of mobile technologies for instructional purpose. & 2.03 & 1.35 \\
S14 - It is a good idea to use mobile technologies for instructional purpose. & 3.15 & .89 \\
S15 - The use of mobile technologies increase students' motivation. & 3.20 & .85 \\
S16 - Mobile technologies may provide greater interaction between teachers and & 2.94 & .98 \\
students. & & 2.96 \\
Overall &
\end{tabular}

* Arranged as negative in terms of meaning

In the instructional use of mobile technologies, the pre-service computer teachers' responses have the mean score of 2.96 at the I agree level. Their perspective about mobile technologies that they facilitate learning was generally positive $(M=3.25)$, and they think by the mobile technologies the instructional process may be more enjoyable $(M=3.20)$, and using mobile devices for instructional purposes is a good idea (3.15).

The pre-service teachers' responses about the future use of mobile technologies were presented in Table 5.

Table 5: Future Use of Mobile Technologies

\begin{tabular}{llr}
\hline Items & M & SD \\
\hline S17 - I will seek opportunities to adopt mobile technologies in my teaching & 2.92 & .96 \\
S18 - I would like to use mobile technologies for my future career development. & 3.24 & .85 \\
S19 - I will recommend my colleagues to use mobile devices. & 3.18 & .89 \\
S20 - I will follow innovations in mobile technologies in the future. & 3.37 & .79 \\
S21 - I will encourage students to use mobile technologies for educational purposes. & 3.23 & .85 \\
S22 - I think the use of mobile devices will be much more common in future. & 3.61 & .72 \\
S23 - I can understand people who find mobile devices boring after some time. & 1.83 & 1.25 \\
Overall & 3.05 & \\
\hline
\end{tabular}

* Arranged as negative in terms of meaning

It is obvious that overall pre-service computer teachers have positive opinions about the future use of mobile devices for educational purposes (3.05). Most of them found the mobile devices will commonly be used in the future (3.61). In addition, they perceived that they will follow these technologies (3.37) and recommend to their colleagues to use mobile technologies in the future (3.37).

Overall, among three factors, only the instructional use factor was evaluated in I agree level (2.96), and other two factors, current use (3.21) and future use (3.05) of mobile technologies was evaluated as I strongly agree level. The scores show that the median scores of the students' perceptions towards the use of mobile technologies in their future practice are between 3 and 4 in all of the three factors. 


\section{Relations between current use, future use and instructional use of mobile technologies}

The Pearson Correlation analysis was applied to determine the relations between the current use, instructional use and future use of mobile technologies. The correlation coefficient was calculated by using the average scores to the items of the three factors and shown in Table 6.

Table 6: Relations among three factors in using mobile technology

\begin{tabular}{llll}
\hline & Current Use & Instructional Use & Future Use \\
\hline Current Use & 1.00 & & \\
Instructional Use & $0.42^{* *}$ & 1.00 & \\
Future Use & $0.42^{* *}$ & $0.69^{* *}$ & 1.00 \\
\hline
\end{tabular}

$* * p<.01$

Positive correlations between three factors are seen in Table 6 . The correlation between current use and instructional use $(\mathrm{r}=.42)$. Similarly, a moderate positive correlation is found between current use and future use $(\mathrm{r}=.42)$. Also, a strong positive correlation is found between instructional use and future use of mobile technologies $(r=0.69)$.

The responses about the factor current use of mobile technologies were outlined in Figure 2.

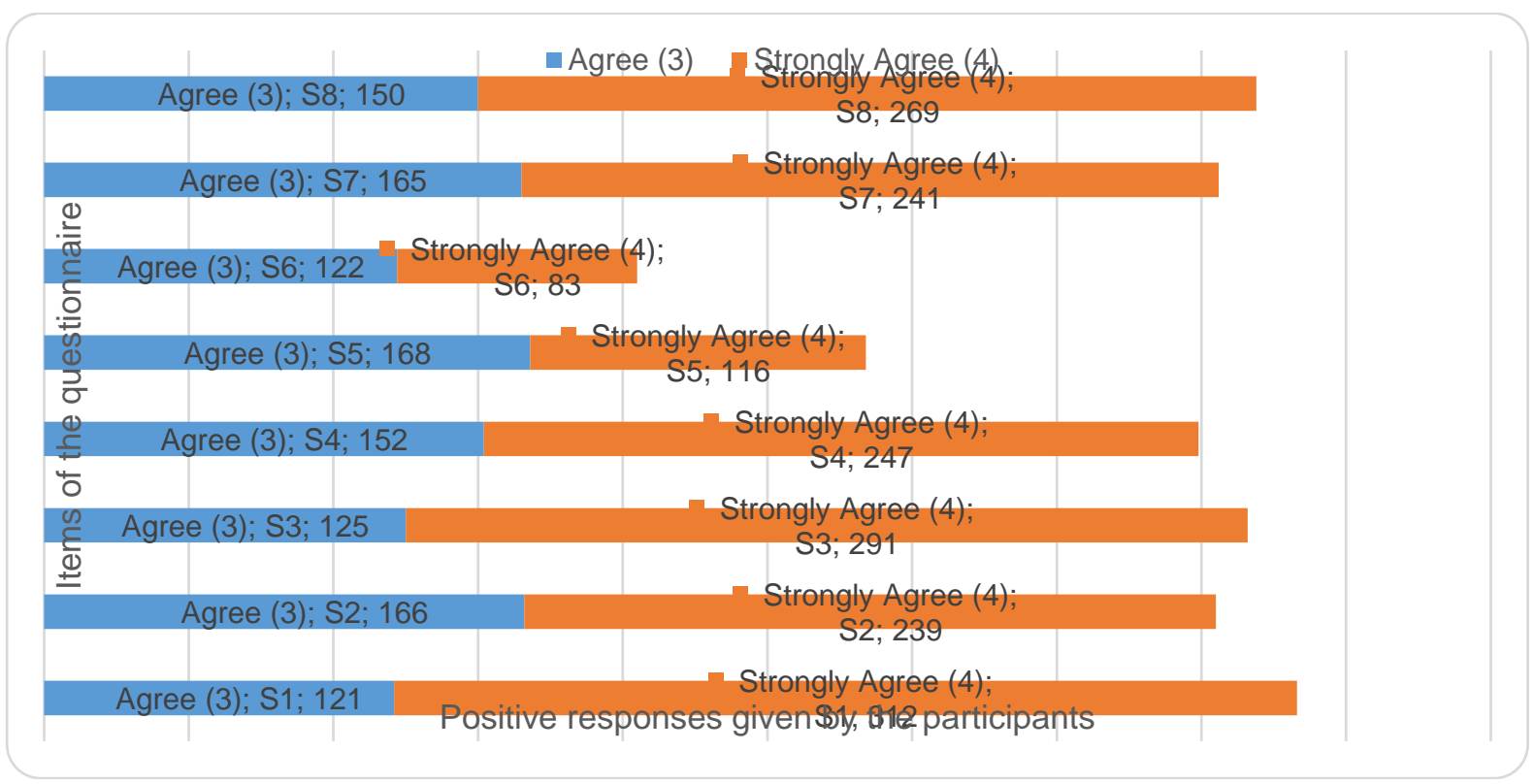

Figure 2. Positive responses of current use of mobile technologies

The responses about "current use of mobile technologies" were generally positive. Pre-service computer teachers addressed that mobile technologies can help them to achieve their work more easily $(\mathrm{N}=406)$, and they perceived that mobile technologies enabled them to access information easily $(\mathrm{N}=419)$. Similarly, some other researchers also reported that mobile technologies may support instructional process. Virvou and Alepis (2005) addressed that with their non-spatial use feature, mobile technologies can help to achieve their work and to enable users to access internet anywhere and at any time. In the instructional use factor, mobile technologies were considered to provide the opportunity for students to access information them wherever and whenever they want. Also, Attewell et al. (2010) argued that learners may use mobile technologies to provide using the time efficiently. 
On the other hand, Frias-Martinez, Virseda, and Gomero (2012) addressed that students' high ownership rates of mobile technologies can facilitate formal education. Mobile technologies may support interaction, communication, and collaboration between student-student and teacherstudent instantly; develop relationships; and support multimedia (Attewell et al., 2010; Behera, 2013). Thus, one of the main concerns about mobile technologies is their usefulness and the other is ease of use. In this study, the items of the questionnaires were taken into consideration in terms of the affordances and benefits of mobile technologies. It is seen that the items are generally in the framework of the acceptance. In this sense the participants' responses indicate the usefulness and ease of use in the context of current use, instructional use and future use. When studying these kinds of factors, explorations and elaborations are generally provided through technology adoption models. Kriek and Stols (2010) suggested the model as one of the useful theoretical frameworks to assess respondents' perspectives and their intention in technology assisted learning environments. Especially in the e-learning studies many examples of the use of TAM suggest to use it at all educational levels (Sánchez-Prieto, Olmos-Migueláñez, \& GarcíaPeñalvo, 2016).

In this circumstance, technology acceptance model (TAM) may provide a way to interpreting participants' preferences about the three factors of the questionnaire. In the model, perceived usefulness is described the enhanced performance which a user has been employed any the technology to perform specific tasks and problem solving (Keller, 2005). In this study pre-service teachers' perspectives about the current use of mobile technologies was considerably positive. In this sense, their positive views as manage their tasks easily (i.e. they may study independent from time and place), access information can be considered as the elements explained within the context of the perceived usefulness factor of the TAM.

In the context of the current use of mobile technologies; participants perceived that it was easy, clear, and understandable to learn and use mobile technologies. Some other studies also reported that users are concerned with some features of mobile technologies (Georgiev, Georgieva \& Smrikarov, 2004; Wu \& Wang, 2005). These features can be considered as the main factors related to the ease of use that the pre-service teachers expressed positive views about the related items. Similarly, Chih-Yung, Chih-Chiang, and Ming-Te (2011) suggested that mobile technologies should be produced with user-friendly features and in ideal design screen format for daily life. In this way people may accept mobile technologies easily. In this study, especially the items include the feature of ease were responded with positive perspectives. These items were generally referred to the ease of use factor of TAM. In this respect, the pre-service teachers' responses about the current use of mobile devices can be evaluated with regard to ease of use of mobile devices.

The distributions of the responses in the factor of instructional use of mobile technologies were presented in Figure 3. 


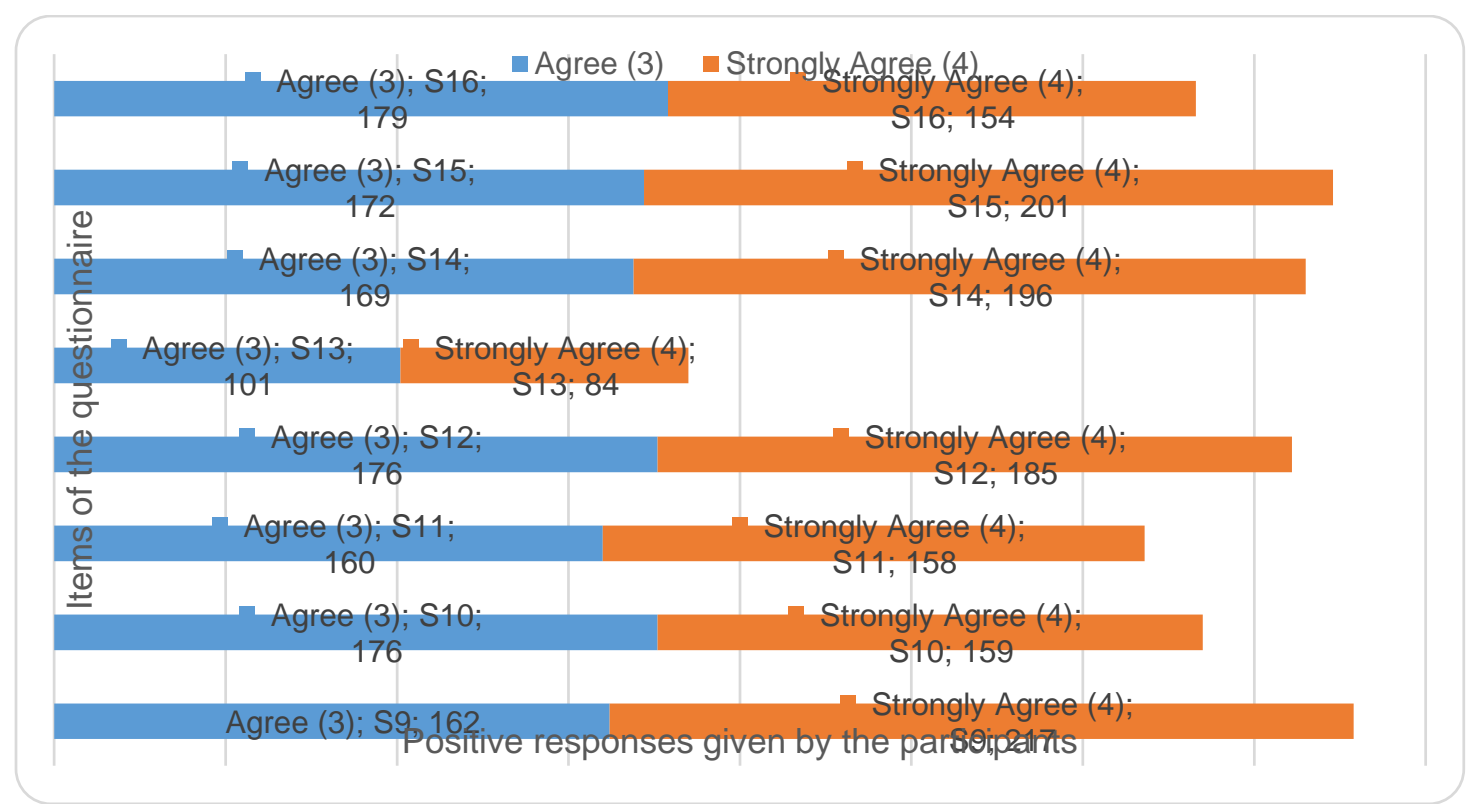

Figure 3. Positive responses about use for instructional purposes

The responses for the items in the factor of instructional purposes such as mobile technologies facilitate instruction, enable the efficient use of time in the teaching-learning process, enhance learning and teaching productivity were the factors may be assessed in the perceived usefulness of TAM. In this study participants perceived that the mobile technologies may facilitate teaching $(\mathrm{N}=379)$ and they will enable to use the time efficiently in the teaching process $(\mathrm{N}=335)$. Also, positive responses were given to the items such as the mobile technologies will increase students' learning performances $(\mathrm{N}=318)$ and they will enhance pre-service teachers' professional productivity $(\mathrm{N}=361)$. These items may be associated with the perceived usefulness. In this sense current perspectives and beliefs can be an indicator of an individual's eventual behaviour. Ma et al., (2005) asserted that attitudes and perspectives may reflect the tendency to react either positively or negatively and the thoughts are significant variable for determining the intention to use technology. In this study the pre-service teachers' perspectives about current use of mobile technologies indicate that current use may play a role in shaping their future intentions of use. In this regard, the responses indicate that using mobile technologies for instructional purposes is a good idea $(\mathrm{N}=365)$ and students may feel enjoyed in the learning process $(\mathrm{N}=373)$. Since these perspectives are related to the future considerations related responses were evaluated in terms of the intentions. 


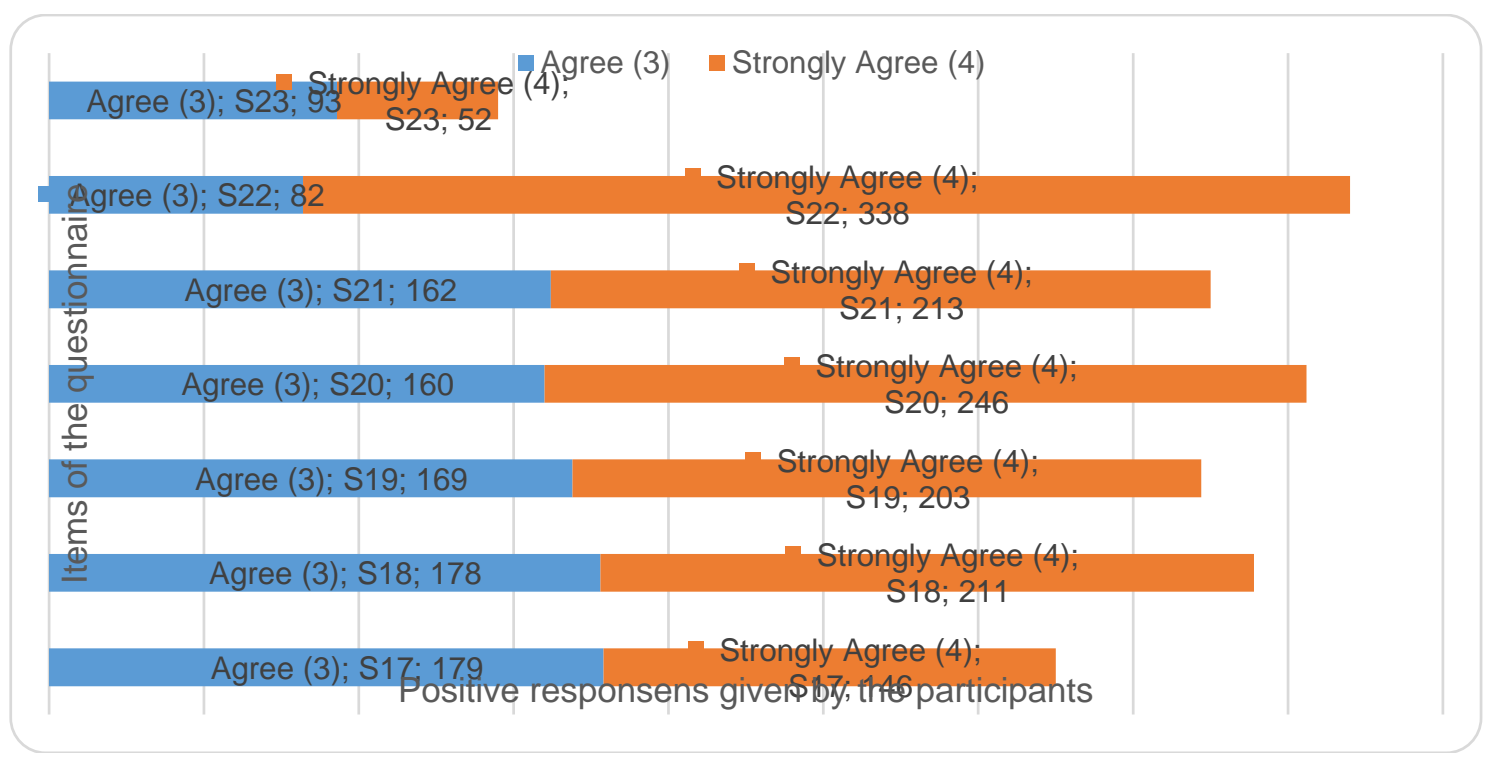

Figure 4. Positive responses about future use

Pre-service teachers' intentions were revealed by their positive views regarding their plans to use mobile technologies in the teaching process in the future. Thus, participants' tendencies towards using mobile technologies in the future were generally positive at the level of I agree (3.05).

Overall, mobile technologies instructional use is somewhat related within the frame of the perceived usefulness and the attitude constructs of TAM. In this sense, Yildiz (2011) pointed out that the willingness to use, perceptions about enjoyable, beliefs about the mobile technologies, following the developments in the mobile technologies, and suggest colleagues to use may be considered in the intention factor of TAM. Within this point of view, the pre-service teachers' acceptance to use, follow, and use mobile technologies continually to take advantage of mobile technologies for their professional development can be determined in terms of the intention. Consequently, the overall relations among TAM factors were briefly presented in Figure 5. On the other hand, Ma et al. (2005) reported that perceived ease of use was not a significant predictor on the intention of adopting technology. Technology adoption intention was correlated with perceived usefulness (instructional use), that is, perceived ease of use (current use) indirectly affected to intention. In fact, in this study it was not surprising that pre-service teachers who hold positive beliefs in current use also have positive views in instructional use. Also, perceptions about future use were positively correlated with current and future use. Thus, it can be considered that the intentions and attitude which can be associated with the factor of future use is positively correlated with the perceived usefulness which can be associated with the factor of current use and also instructional use which is referred as easier to use of mobile technologies in classrooms. Similarly, Hur et al. (2015) found that the use of mobile technologies make the teaching practice more effective who believe that mobile devices to be easy to use.

Teo (2012) pointed out that the subordinate elements which are evaluated positively in ease of use, perceived usefulness and intention match up a great deal with the characteristics which elaborate the studies of TAM constructs. So we tried to match links between TAM constructs and the items of the questionnaire including current, instructional and future uses. Taking the perspectives as a reference, some items of the current use factor were associated with perceived ease of use and some others were associated with perceived usefulness. While all of the items about the factor of instructional use were related with perceived usefulness, the items of future use were linked to the attitude and intention construct of the TAM. The links between preservice teachers' perspectives and the TAM constructs is shown in Figure 5. 


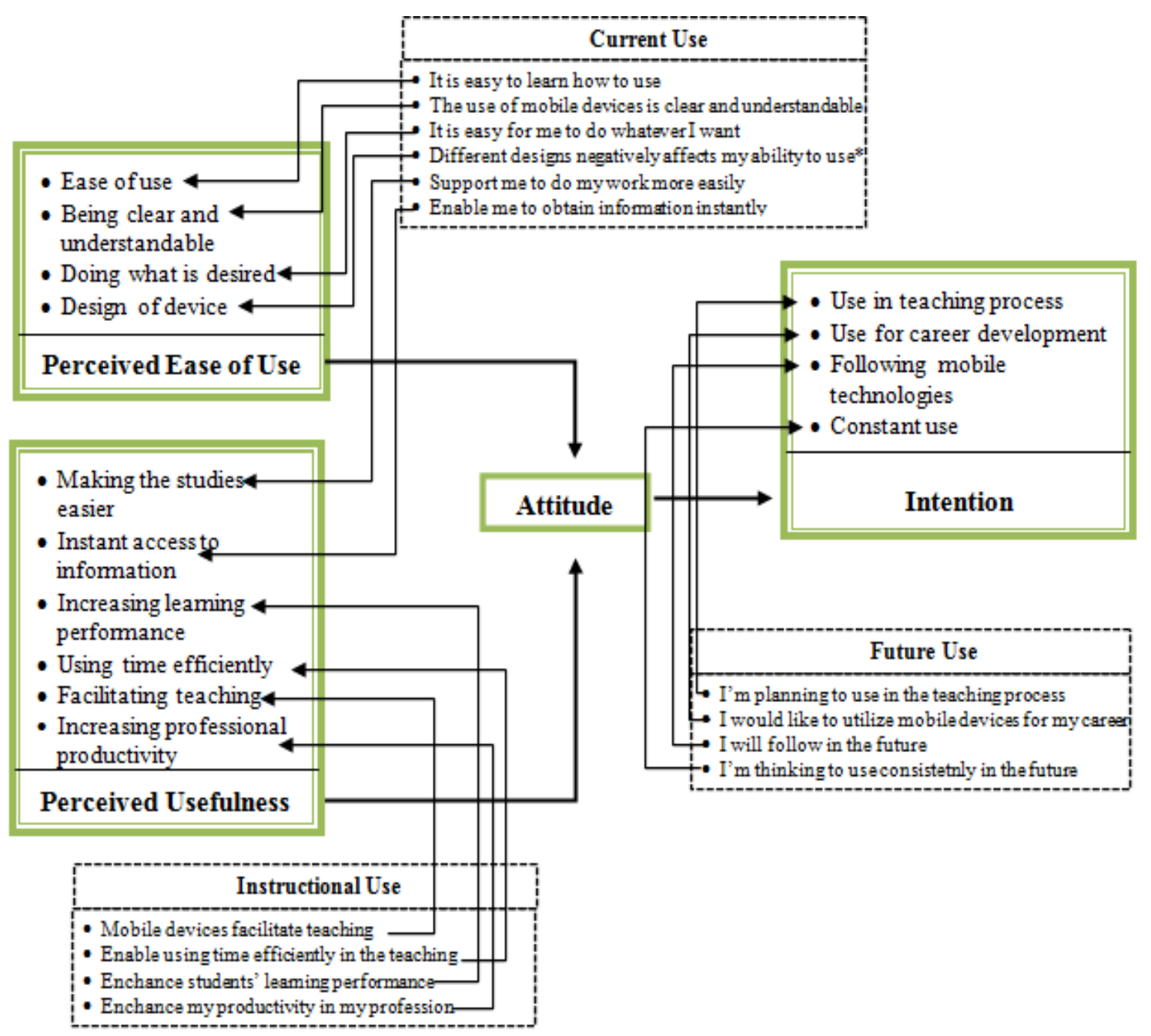

Figure 5. Relationships between pre-service teachers' perspectives and TAM

According to TAM, people form attitudes and intentions toward trying to learn to use the new technology prior to initiating efforts directed at using (Bagozzi, Davis, \& Warshaw, 1992). Lee, Cheung, and Chen (2005) in their study found that university students' perceived usefulness had an impact on both students' attitude toward and intention to use towards e-learning. Also (Saadé, Nebebe, \& Tan, 2007) pointed out that behavioural intention and attitude towards e-learning were effected from perceived ease of use and perceived usefulness. To this end perceived usefulness and the ease of use may be considered as an indicator for the intention (Mun \& Hwang, 2003). The results of the study show that pre-service computer teachers' perspectives about the mobile technologies as usefulness $(\mathrm{M}=3.19)$ and ease of use $(\mathrm{M}=3.18)$, and their intentions to use in the future $(\mathrm{M}=3.28)$. Based on the results their tendencies to use mobile technologies in the future may be explained by attitudes and intention constructs of the TAM. In this regard, the correlations between instructional use of mobile technologies reflecting the perceived usefulness and future use had found significant and positive. In another study Darren Pullen et al. (2015) also concluded that pre-service teachers' perceived ease of use of technology was significantly predictive of the intention of use.

This study has also some limitation regarding the self-designed questionnaire items for variables about the mobile technologies use intention, perceived ease of use and perceived usefulness. Since the reliability of the sub-sections of the questionnaire is acceptable, the results may need a further confirmation on its generalizability. 


\section{Conclusion and recommendations}

This study addressed potential links between the teachers' current use of mobile technologies and intentions to use the mobile technologies in their future practices. The results were important because participants were pre-service computer teachers actually without the opportunities incorporate mobile technologies in their real practices, but in their profession they should work within those technologies. Pre-service computer teachers' perspectives about current use, instructional use and future use of the mobile technologies were generally positive. The positive results about current position reflect some clues about shaping the future positively in terms of tendencies. Hence, high correlations between current use and instructional use; current use and future use indicate that current experiences about mobile technologies are so important for future teaching practices in terms of mobile learning applications.

In this study TAM is used in order to discuss perspectives of the pre-service teachers in order to explore the current and future position. While TAM is generally used to assess individuals' current views or behaviours about accepting or adapting to the new technologies (Edmunds, Thorpe, \& Conole, 2012; Escobar-Rodriguez \& Monge-Lozano, 2012), a conclusion may be derived from this study that TAM may also be useful to explain the tendencies in the future use of technology for different purposes (i.e. for instructional purposes).

When the pre-service computer teachers' perspectives about current use of mobile technologies are taken into consideration, it is inevitable that teachers should include mobile technologies in terms of technology integration in the classrooms. In this case, it will be useful to present some examples of applications about integrating mobile technologies to the classrooms in teacher training. Also, computer teachers as leaders of using innovations in the schools should be informed about the adoption processes in order to helps their future colleagues in the schools.

In this study the technology aspect of mobile technologies is generally related to the ease of use, and the mobile aspect is related to usefulness. So, further investigation can be conducted to determine the perceived ease of use of technology and usefulness of mobility on the intentions of future uses. Thus pre-service teachers' views about the design features of the mobile devices may be paid attention by technology designers. Future studies may focus on investigating possible emerging barriers that may discourage pre-service computer teachers in the future. Also inservice teachers' mobile technology adoption perspectives may be investigated in order to test the pre-service teachers' current views. This study with the insight for using mobile technologies in the future is hoped to contribute to the efforts on adoption processes of mobile technologies in to the classrooms.

\section{References}

1. Acarli, D. S., \& Sağlam, Y. (2015). Investigation of pre-service teachers' intentions to use of social media in teaching activities within the framework of technology acceptance model. Procedia-Social and Behavioral Sciences, 176, 709-713.

2. Aktaş, S. (2007). An application on technology acceptance model and accountants' use of information technology. (Unpublished master's thesis). Gebze Institute of Technology, Turkey.

3. Attewell, J., Savill-Smith, C., Douch, R., \& Parker, G. (2010). Modernising education and training: Mobilising technology for learning. London: Regent Arcade House.

4. Bagozzi, R. P., Davis, F. D., \& Warshaw, P. R. (1992). Development and test of a theory of technological learning and usage. Human relations, 45(7), 659-686. 
5. Baydas, O., \& Göktaş, Y. (2016). Influential factors on pre-service teachers' intentions to use ICT in future lessons. Computers in Human Behavior, 56, 170-178.

6. Behera, S. (2013). M-learning: A new learning paradigm. International Journal on New Trends in Education \& Their Implications, 4(2), 24-34.

7. Cacho, R. M. (2017). Student teachers' smartphone academic uses and preferences: Perspectives for mobile-aided pedagogy. Proceedings of the International Conference on ICT and Knowledge Engineering, 57-61. doi:10.1109/ICTKE.2016.7804099

8. Camilleri, V., \& Montebello, M. (2011, May). Virtual World Presence for Pre-service Teachers: Does the TAM Model Apply? Proceedings of the Games and Virtual Worlds for Serious Applications (VS-GAMES), 2011 Third International Conference on, 156-159. IEEE.

9. Chen, F. H., Looi, C. K., \& Chen, W. (2009). Integrating technology in the classroom: a visual conceptualization of teachers' knowledge, goals and beliefs. Journal of Computer Assisted Learning, 25(5), 470-488.

10. Chih-Yung, T., Chih-Chiang, W., \& Ming-Te, L. (2011). Using the technology acceptance model to analyze ease of use of a mobile communication system. Social Behavior \& Personality: An International Journal, 39(1), 65-69.

11. Creswell, J. W. (2005). Educational research: Planning, conducting, and evaluating quantitative and qualitative research ( $2^{\text {nd }}$ ed.). Upper Saddle River, N.J.: Pearson Merrill Prentice Hall.

12. Darren Pullen, J. F., Swabey, K., Abadooz, M., \& Sing, T. K. R. (2015). Pre-service teachers' acceptance and use of mobile learning in Malaysia. Australian Educational Computing, 30(1).

13. Davis, F. D., Bagozzi, R. P., \& Warshaw, P. R. (1989). User acceptance of computer technology: a comparison of two theoretical models. Management Science, 35(8), 982-1003.

14. Dexter, S., Doering, A. H., \& Riedel, E. S. (2006). Content area specific technology integration: A model for educating teachers. Journal of Technology and Teacher Education, 14(2), 325.

15. Edmunds, R., Thorpe, M., \& Conole, G. (2012). Student attitudes towards and use of ICT in course study, work and social activity: A technology acceptance model approach. British Journal of Educational Technology, 43(1), 71-84.

16. Escobar-Rodriguez, T., \& Monge-Lozano, P. (2012). The acceptance of Moodle technology by business administration students. Computers \& Education, 58(4), 1085-1093.

17. Frias-Martinez, V., Virseda, J, \& Gomero, A. (2012, September). Mobilizing education: Evaluation of a mobile learning tool in a low-income school. Paper presented at the $14^{\text {th }}$ International Conference on Human-Computer Interaction with Mobile Devices and Services, San Francisco, USA.

18. Fulantelli, G., Taibi, D., \& Arrigo, M. (2015). A framework to support educational decision making in mobile learning. Computers in Human Behavior, 47, 50-59.

19. Georgiev, T., Georgieva, E., \& Smrikarov, A. (2004, June). M-learning-a new stage of e-learning. Paper presented at the International Conference on Computer Systems and Technologies, Rousse, Bulgaria.

20. Goktas, Y., Yildirim, S., \& Yildirim, Z. (2009). Main barriers and possible enablers of ICTs integration into pre-service teacher education programs. Educational Technology \& Society, 12(1), 193-204. 
21. Holden, H., \& Rada, R. (2011). Understanding the influence of perceived usability and technology self-efficacy on teachers' technology acceptance. Journal of Research on Technology in Education, 43(4), 343-367.

22. Hu, P., Clark, T. H., \& Ma, W. W. (2003). Examining technology acceptance by school teachers: A longitudinal study. Information \& Management, 41(2), 227-241.

23. Jaradat, M. I. R. (2013). Applying the technology acceptance model to the introduction of mobile voting. International Journal of Mobile Learning and Organisation, 7(1), 29-47.

24. Joo, Y. J., Lee, H. W., \& Ham, Y. (2014). Integrating user interface and personal innovativeness into the TAM for mobile learning in Cyber University. Journal of Computing in Higher Education, 26(2), 143-158.

25. Kafyulilo, A. (2014). Access, use and perceptions of teachers and students towards mobile phones as a tool for teaching and learning in Tanzania. Education \& Information Technologies, 19(1), 115-127.

26. Keller, C. (2005). Virtual learning environments: Three implementation perspectives. Learning, Media \& Technology, 30(3), 299-311.

27. Kim, D., Chun, H., \& Lee, H. (2014). Determining the factors that influence college students' adoption of smartphones. Journal of the Association for information Science and Technology, 65(3), 578-588.

28. Kriek, J., \& Stols, G. (2010) Teachers' beliefs and their intention to use interactive simulations in their classrooms. South African Journal of Education, 30(3), 439-456.

29. Koca, M. (2006). Examining teachers? Use of information and communication technology according to variables of unified model of information and communication technology. (Unpublished master's thesis). Hacettepe University, Turkey.

30. Kuo, K. M., Liu, C. F., \& Ma, C. C. (2013). An investigation of the effect of nurses' technology readiness on the acceptance of mobile electronic medical record systems. BMC medical informatics and decision making, 13(1), 88.

31. Kusskonmaz, H. (2011). Determining teacher's perception of mobile learning at secondary schools. (Unpublished master's thesis). Bahçeşehir University, Turkey.

32. Lee, M. K., Cheung, C. M., \& Chen, Z. (2005). Acceptance of Internet-based learning medium: the role of extrinsic and intrinsic motivation. Information \& management, 42(8), 10951104

33. Ma, W. W., Andersson, R. R., \& Streith, K. O. (2005). Examining user acceptance of computer technology: An empirical study of student teachers. Journal of Computer Assisted Learning, 21(6), 387-395.

34. Menzi, N., Önal, N., \& Çalışkan, E. (2012). Investigating educational researchers’ views of using mobile technologies for educational purposes based on technology acceptance model. Ege Journal of Education, 13(1), 40-55.

35. Mun, Y. Y., \& Hwang, Y. (2003). Predicting the use of web-based information systems: selfefficacy, enjoyment, learning goal orientation, and the technology acceptance model. International journal of human-computer studies, 59(4), 431-449.

36. Murray, O. T., \& Olcese, N. R. (2011). Teaching and learning with iPads, ready or not? TechTrends, 55(6), 42-48. 
37. Nistor, N. (2014). When technology acceptance models won't work: Non-significant intention-behavior effects. Computers in Human Behavior, 34, 299-300.

38. Park, S., Nam, M., \& Cha, S. (2012). University students' behavioral intention to use mobile learning: Evaluating the technology acceptance model. British Journal of Educational Technology, 43(4), 592-605.

39. Phuangthong, D., \& Malisawan, D. (2005, August). A study of behavioral intention for $3 G$ mobile internet technology: Preliminary research on mobile learning. Paper presented at the $2^{\text {nd }}$ International Conference on eLearning for Knowledge-Based Society, Bangkok, Thailand.

40. Saadé, R., Nebebe, F., \& Tan, W. (2007). Viability of the "Technology Acceptance Model" in multimedia learning environments: A comparative study. Journal of Knowledge \& Learning Objects, 3(1), 175-184.

41. Sánchez-Prieto, J. C., Migueláñez, S. O., \& García-Peñalvo, F. J. (2014). ICTs integration in education: mobile learning and the technology acceptance model (TAM). Proceedings of the Second International Conference on Technological Ecosystems for Enhancing Multiculturality, 683-687. ACM.

42. Sánchez-Prieto, J. C., Olmos-Migueláñez, S., \& García-Peñalvo, F. J. (2016). Informal tools in formal contexts: Development of a model to assess the acceptance of mobile technologies among teachers. Computers in Human Behavior, 55.

43. Teo, T. (2012). Examining the intention to use technology among pre-service teachers: An integration of the technology acceptance model and theory of planned behavior. Interactive Learning Environments, 20(1), 3-18.

44. Turan, B. (2011). The research of the usage of information and communication technologies via technology acceptance model and an application on elementary school teachers. (Unpublished master's thesis). Bilecik Şeyh Edebali University, Turkey.

45. Uzunboylu, H., \& Ozdamli, F. (2011). Teacher perception for m-learning: Scale development and teachers' perceptions. Journal of Computer Assisted Learning, 27(6), 544-556.

46. Valtonen, T. (2011). An insight into collaborative learning with ICT: Teachers' and students' perspectives. University of Eastern Finland.

47. Valtonen, T., Kukkonen, J., Kontkanen, S., Sormunen, K., Dillon, P., \& Sointu, E. (2015). The impact of authentic learning experiences with ICT on pre-service teachers' intentions to use ICT for teaching and learning. Computers \& Education, 81, 49-58.

48. Virvou, M., \& Alepis, E. (2005). Mobile educational features in authoring tools for personalised tutoring. Computers \& Education, 44, 53-68.

49. Wang, R., Wiesemes, R., \& Gibbons, C. (2012). Developing digital fluency through ubiquitous mobile devices: Findings from a small-scale study. Computers \& Education, 58(1), 570-578.

50. Wang, Y., Wu, M., \& Wang, H. (2009). Investigating the determinants and age and gender differences in the acceptance of mobile learning. British Journal of Educational Technology, 40(1), 92-118.

51. Wu, J. H., \& Wang, S. C. (2005). What drives mobile commerce? An empirical evaluation of the revised technology acceptance model. Information \& management, 42(5), 719-729.

52. Yamakawa, P., Delgado, C., Díaz, E., Garayar, E., \& Laguna, H. (2013). Factors influencing the use of mobile technologies in a university environment: A case from Latin America. International Journal of Information and Communication Technology Education (IJICTE), 9(2), 24-38. 
53. Yong-Wee, S., Siong-Hoe, L., Kung-Keat, T., Check-Yee, L., \&Parumo, S. (2010). Prediction of user acceptance and adoption of smart phone for learning with technology acceptance model. Journal of Applied Sciences, 10(20), 2395-2402.

54. Yuen, A. H., \& Ma, W. W. (2008). Exploring teacher acceptance of e-learning technology. Asia-Pacific Journal of Teacher Education, 36(3), 229-243. 